\title{
Improved Quality of Quail's Egg after the Induction of Hepatitis B Vaccine and Curcumin
}

\author{
Tyas Rini Saraswati* and Silvana Tana \\ Department of Biology, Faculty of Science and Mathematics, Universitas Diponegoro,Tembalang Campus, Semarang 50275, Indonesia \\ *Corresponding author's Email: tyasrinisaraswati@ lecturer.undip.ac.id; ORCID: 0000-0002-8038-1864
}

Received: 24 Apr 2021

Accepted: 01 June 2021

\begin{abstract}
The present study aimed to observe the quality of quails' eggs after being vaccinated with hepatitis B vaccine and given supplements of curcumin and turmeric powder. A total of 36 female quails at the age of 10 days were divided into four groups, including the control (P0), vaccinated with hepatitis B vaccine (P1), vaccinated with hepatitis B vaccine and given $12 \mathrm{mg} /$ quail/day of supplement curcumin (P2), and vaccinated with hepatitis B vaccine and given $108 \mathrm{mg}$ /quail/day of supplement turmeric powder (P3). Vaccination was given twice, at the age of 32 and 60 days. The curcumin and turmeric powder were given every day until the age of three months. The results showed significantly different outcomes on glutamic pyruvate transaminase serum, glutamic oxaloacetic transaminase serum, egg production (percentage of carbohydrates, protein, fat, cholesterol), and the physical quality of eggs, but it was not significantly different towards the liver weight. It can be concluded that quails vaccinated with hepatitis B vaccine and treated with supplements of curcumin and turmeric powder could improve liver function and increase egg production with better chemical and physical qualities.
\end{abstract}

Keywords: Curcumin, Egg, Follicle hierarchy, Liver function, Quail

\section{INTRODUCTION}

The hepatitis B virus threatens millions of people and has infected two billion people in the world so far (Jefferies et al., 2018). Out of whom, 240 million individuals become chronic hepatitis B sufferers (Ott et al., 2012). More than 686,000 people die each year due to complications from this disease (Nelson et al., 2016). In Indonesia, hepatitis has reached the rate of $4-20.3 \%$ (Renantriandani et al., 2020). There are around $15-40 \%$ of human patients suffering from chronic hepatitis leading to liver cirrhosis (Shweta and Prasad, 2016).

Until now, a treatment for hepatitis B patients is only providing painkillers, so as not to worsen the symptoms that appear. To handle the disease, drugs having function are suggested to inhibit viremia and prevent damages to the liver. Hepatitis B vaccination is an effort to increase the body's immunity by forming antibodies (Damme, 2016). Many adult human patients recover from the infection, but $5-10 \%$ of them will not be totally clean from the virus due to the failure to provide an adequate immune response leading to severe hepatitis B infection. This infection can be an inactive career or can have chronic hepatitis showing no symptoms, but this infection remains extremely serious and can result in liver damages or cirrhosis, liver cancer, and death (Liang, 2009).

Female quails vaccinated with hepatitis B produce a specific concentration of antibodies (towards hepatitis B). Antibodies formed in quails' blood can be transferred into the eggs. These transferred antibodies are called Immunoglobulin Yolk (Munhoz et al., 2014). Egg production in quails can be increased by inducing the formation of egg yolk (vitellogenin). This can be done by supplementing curcumin and turmeric powder. The results showed that the addition of turmeric powder in the quails' food enhanced the bio-synthesis of vitellogenin (Saraswati et al., 2013a) so that it can increase the hierarchy of ovarian follicles in quails (Saraswati et al., 2013a) and also chickens (Saraswati et al., 2014). This is because of the presence of curcumin in turmeric which has hepatoprotective properties. Turmeric powder contains $7.97 \%$ of curcumin which could enhance the function of the liver (Saraswati et al., 2013b). Other than curcumin, 
turmeric powder also contains $6.79 \%$ phytoesterogen (Saraswati et al., 2013b). The estrogenic effects of phytoestrogens can increase the vitellogenin protein synthesis (Ravindar et al., 2007; Levi et al., 2009). Moreover, the phytoestrogen diet could cause large changes in the vitellogenin plasma level (Turker and Bozcaarmutlu, 2009). Turmeric also contains fat, carbohydrates, protein, starch, vitamin $\mathrm{C}$, and mineral salts, namely iron, phosphorus, and calcium. The addition of turmeric powder supplements up to the amount of 108 $\mathrm{mg}$ /quail/day could lead to higher plasma vitellogenin levels (Saraswati et al., 2013a). Curcumin which has the molecular formula $\mathrm{C} 21 \mathrm{H} 20 \mathrm{O} 6$ with a molecular weight of 368.91 modulates and accelerates cell regeneration (Gantait et al., 2011; Ravindar et al., 2007). This substance has antioxidant activity, inhibits lipid peroxidation (Kohli et al., 2005), and also is the potential to be antiinflammatory (Chattopadhyay et al., 2004; Nagpal and Sood, 2013).

vitellogenin, anti-hepatitis antibodies, and other results of liver metabolism are taken to the ovarian follicles to arrange egg yolks, so that the number of follicular hierarchies will increase and the number of produced eggs will be higher with better quality nutrient content. Egg production containing anti-hepatitis antibodies can be used as an alternative to immunotherapy, which is a new innovation in the treatment, and can be used as prevention of the development of hepatitis B and cirrhosis of the liver.

\section{MATERIALS AND METHODS}

\section{Ethical approval}

This research was under the approval of the Ethics Commission on Health Research at the Faculty of Medicine, Universitas Diponegoro, Semarang, Indonesia with No.123/EC/H/FK-UNDIP/XI/2018.

\section{Materials}

The present study was conducted on 100 female quails aged 8 days from quail breeders in Colomadu, Boyolali, Central Java, Indonesia. The quails were acclimated in collective cages at the size of $1 \times 1 \times 1$ meters for 2 weeks. In collective cages given 40-watt light. The temperature of the environment was around $25-28^{\circ} \mathrm{C}$ with humidity of $60-80 \%$. The quails were fed with a standard diet (merk HI-PRO-VITE 594) containing $19.5 \%$ of protein, $3 \%$ of fat, $8 \%$ of fiber, $7 \%$ of ash, $0.9 \%$ of calcium, and $0.6 \%$ of phosphor, and drinking water was prepared ad libitum during the experiment. Newcastle
Disease 2 (ND2) vaccine was given at the age of 21 days. Vita chick at the dose of $0.7 \mathrm{~g} / \mathrm{L}$ drinking water (containing A, D, E, K, B1, B2, B3, B12 vitamins, and Calcium-D-pantothenate) was given after vaccination.

\section{Methods}

\section{Experiment procedure}

The experiment was done using a fully random design method. A total of 100 quails were divided into four groups equally; namely the control group (P0), quails vaccinated with the hepatitis $B$ vaccine $(P 1)$, quails vaccinated with the hepatitis $B$ vaccine (Engerix $B$ by VAXCORP, Indonesia) and given $12 \mathrm{mg} /$ quail/day of curcumin supplement (P2), and quails vaccinated with hepatitis $\mathrm{B}$ vaccine and given $108 \mathrm{mg} /$ quail/day of turmeric powder supplement (P3). Vaccinations $(0.02 \mathrm{~mL}$ for each quail) were given twice, at the age of 32 days and 60 days. Turmeric powder was dissolved in $1.25 \mathrm{~mL}$ distilled water, and given orally using a gavage/sonde needle every day until the age of three months. The observed parameters were the number of follicular hierarchy, egg production, egg weight, protein, carbohydrate, fat, egg cholesterol, egg yolk index, Haugh Unit, eggshell index, and liver function (Serum Glutamic Piruvic Transaminase (SGPT) levels, Serum Glutamic Oxaloacetic Transaminase (SGOT), and liver weight).

\section{Blood collection}

At the end of the treatments, the blood samples were taken from the jugular vein, collected in Eppendorf tubes, and centrifuged with a mini diagnostic tool at the speed of $3000 \mathrm{rpm}$ for 20 minutes to get the serum.

\section{Measurement of the parameters and data analysis}

The measurement of liver function was carried out by measuring SGPT and SGOT levels in the blood. The SGPT analysis was done using a method recommended by the International Federation of Clinical Chemistry (IFCC), while for SGOT IFCC UV kinetic method was used (Mahaboob et al., 2013).

The egg production was calculated from the beginning of the laying process until the end of the treatment. The calculation included the number of developed hierarchies of ovarian follicles. The analyzed chemical quality of the eggs were egg protein levels by the Kjedahl method (Puwastien et al., 2011), egg carbohydrate levels, egg fat content by the Soxhlet method (Puwastien et al., 2011), and egg cholesterol levels by the Lieburmann Burchard method (Puwastien et al., 2011). The length, width, and diameter of the egg were measured by the 
caliper. The yolk index was determined based on the ratio of yolk height to yolk diameter. Haugh unit was determined by the formula of Haugh unit: $100 \log (\mathrm{h}+7.6$ - 1.7W0.37), where $\mathrm{h}$ is the albumen height $(\mathrm{mm})$, and $\mathrm{W}$ denotes the egg weight (g) (Ogunwole et al., 2015). The obtained data were analyzed using ANOVA followed by the Duncan test with a significance level of 0.05 (Mattjik and Sumertajaya, 2006). Overall analysis was done using SPSS Windows software.

\section{RESULTS}

\section{Liver function and egg production}

There was an improvement in liver function in all treatment groups; P1, P2, and P3 as indicated by a decrease in SGPT levels and an increase in egg productivity (Table 1). Although the liver weight did not increase significantly, based on the color of the liver, the treated quails looked brighter than the control group (Figure 1).

\section{Chemical quality of eggs}

The increase in the chemical quality of eggs produced by the quails vaccinated with the hepatitis B vaccine was indicated by a decrease in carbohydrate and cholesterol levels and an increase in egg protein levels. The provision of curcumin and turmeric powder to quails that have been vaccinated with the hepatitis B vaccine can reduce fat and cholesterol levels, and increase egg protein levels (Table 2).

\section{Physical quality of eggs}

The improvement of physical quality of quails' eggs in the form of an increase in Egg axis length, Egg weight, Egg white weight, and Haugh Unit (HU) occurred in P1, $\mathrm{P} 2$, and P3. The increase in yolk weight occurred in P2 which was given curcumin. A higher amount of yolk height and Yolk Index in treatment P1 and P2 was also observed. An increase in Egg white height at P1, while Egg axis width and Yolk diameter did not show any difference with the control group (Table 3). It was observed that in all treatments, the egg size appeared to be larger than those of the control egg (Figure 2).

\section{Hierarchy follicle}

The follicular hierarchy in quails' ovaries both in the control (P0) and those treated groups (P1, P2, and P3) showed that the development of follicles reached F4-F6 (The number shows the developed ovarian follicle; e.g. F4 is if there were four developed ovarian follicles). However, in P2 and P3 treatments, the number of follicular hierarchies that reached F6 was higher than those of P0 and P1 (Table 4). Based on Figure 3, the number of non-hierarchical follicles at $\mathrm{P} 0$ was the least.

Table 1. Effects of hepatitis B vaccination, curcumin, and turmeric powder on the liver function and egg production of quails

\begin{tabular}{lcccc}
\hline Parameter & P0 & P1 & P2 & P3 \\
\hline Liver weight (g) & $4.62^{\mathrm{a}} \pm 0.59$ & $4.06^{\mathrm{a}} \pm 0.29$ & $4.03^{\mathrm{a}} \pm 0.27$ & $4.29^{\mathrm{a}} \pm 0.13$ \\
SGPT (U/L) & $34.20^{\mathrm{a}} \pm 0.22$ & $32.61^{\mathrm{b}} \pm 0.34$ & $33.75^{\mathrm{b}} \pm 0.28$ & $33.12^{\mathrm{b}} \pm 0.64$ \\
SGOT (U/L) & $30.6^{\mathrm{a}} \pm 0.45$ & $30.69^{\mathrm{a}} \pm 0.75$ & $30.32^{\mathrm{a}} \pm 0.59$ & $31.03^{\mathrm{a}} \pm 0.36$ \\
Egg production/quail & $8^{\mathrm{b}} \pm 1.5$ & $18^{\mathrm{a}} \pm 2.1$ & $19^{\mathrm{a}} \pm 4.5$ & $16^{\mathrm{a}} \pm 3.2$ \\
\hline
\end{tabular}

Similar superscript letters in arow shows no significant difference in the result ( $\mathrm{p}>0.05$ ). P0: Control, P1: Vaccinated with hepatitis B vaccine, P2: Vaccinated with hepatitis B vaccine and given $12 \mathrm{mg} /$ quail/day of curcumin supplement, P3: Vaccinated with hepatitis B vaccine and given $108 \mathrm{mg} / \mathrm{quail} / \mathrm{day}$ of turmeric powder supplement. SGPT: Serum Glutamic Piruvic Transaminase. SGOT: Serum Glutamic Oxaloacetic Transaminase

Table 2. Effects of hepatitis B vaccination, curcumin, and turmeric powder treatment on the chemical quality of eggs

\begin{tabular}{lcccc}
\hline Parameter & P0 & P1 & P2 & P3 \\
\hline Carbohydrate (\%) & $0.8^{\mathrm{a}}$ & $0.72^{\mathrm{b}}$ & $0.74^{\mathrm{ab}}$ & $0.78^{\mathrm{ab}}$ \\
Protein (\%) & $11.02^{\mathrm{b}}$ & $12.05^{\mathrm{a}}$ & $12.25^{\mathrm{a}}$ & $12.33^{\mathrm{a}}$ \\
Fats (\%) & $10.09^{\mathrm{a}}$ & $10.04^{\mathrm{a}}$ & $9.46^{\mathrm{b}}$ & $9.51^{\mathrm{b}}$ \\
Cholesterol (mg/100g) & $78.01^{\mathrm{a}}$ & $73.09^{\mathrm{b}}$ & $69.3^{\mathrm{b}}$ & $67.16^{\mathrm{b}}$
\end{tabular}

Similar superscript letters in arow shows no significant difference in the result ( $>$ > 0.05). P0: Control, P1: Vaccinated with hepatitis B vaccine, P2: Vaccinated with hepatitis B vaccine and given $12 \mathrm{mg} /$ quail/day of curcumin supplement, P3: Vaccinated with hepatitis B vaccine and given $108 \mathrm{mg} / \mathrm{quail} / \mathrm{day}$ of turmeric powder supplement 
Table 3. Effects of hepatitis B vaccination and curcumin and turmeric powder treatment on the physical quality of eggs

\begin{tabular}{|c|c|c|c|c|}
\hline Parameter & P0 & P1 & $\mathbf{P 2}$ & $\mathbf{P 3}$ \\
\hline Egg axis length (mm) & $30.5^{\mathrm{b}}$ & $32.02^{\mathrm{a}}$ & $31.84^{\mathrm{a}}$ & $32.18^{\mathrm{a}}$ \\
\hline Egg axis width (mm) & $24.35^{\mathrm{a}}$ & $24.68^{\mathrm{a}}$ & $25.67^{\mathrm{a}}$ & $24.76^{\mathrm{a}}$ \\
\hline Egg weight $(\mathrm{g})$ & $9.4^{\mathrm{b}}$ & $10.54^{\mathrm{a}}$ & $11.08^{\mathrm{a}}$ & $11.56^{\mathrm{a}}$ \\
\hline Yolk weight (g) & $3.42^{\mathrm{b}}$ & $3.33^{\mathrm{b}}$ & $3.77^{\mathrm{a}}$ & $3.33^{\mathrm{b}}$ \\
\hline Egg white weight (g) & $4.36^{\mathrm{b}}$ & $5.5^{\mathrm{a}}$ & $5.62^{\mathrm{a}}$ & $4.66^{\mathrm{ab}}$ \\
\hline Yolk diameter (mm) & $24.68^{\mathrm{a}}$ & $25.0^{\mathrm{a}}$ & $25.24^{\mathrm{a}}$ & $25.24^{\mathrm{a}}$ \\
\hline Yolk height (mm) & $9.59^{\mathrm{b}}$ & $10.26^{\mathrm{a}}$ & $10.34^{\mathrm{a}}$ & $8.95^{\mathrm{b}}$ \\
\hline Egg white height (mm) & $6.5^{\mathrm{b}}$ & $7.26^{\mathrm{a}}$ & $6.54^{\mathrm{b}}$ & $6.52^{\mathrm{b}}$ \\
\hline Egg shell thickness (mm) & $0.03^{\mathrm{b}}$ & $0.05^{\mathrm{a}}$ & $0.06^{\mathrm{a}}$ & $0.03^{\mathrm{b}}$ \\
\hline Yolk Index & $0.37^{\mathrm{b}}$ & $0.41^{\mathrm{a}}$ & $0.41^{\mathrm{a}}$ & $0.35^{\mathrm{b}}$ \\
\hline Haugh Unit & $65.92^{\mathrm{b}}$ & $87.7^{\mathrm{a}}$ & $93.43^{\mathrm{a}}$ & $92.5^{\mathrm{a}}$ \\
\hline
\end{tabular}

Similar superscript letters in arow shows no significant difference in the result ( $\mathrm{p}>0.05)$. P0: Control, P1: Vaccinated with hepatitis B vaccine, P2: Vaccinated with hepatitis B vaccine and given $12 \mathrm{mg} /$ quail/day of curcumin supplement, P3: Vaccinated with hepatitis B vaccine and given $108 \mathrm{mg} /$ quail/day of turmeric powder supplement

Table 4. Hierarchy table of hepatitis B vaccinated quails' follicles and supplemented with curcumin and turmeric powder

\begin{tabular}{|c|c|c|c|c|c|c|}
\hline \multirow{2}{*}{ Group } & \multicolumn{6}{|c|}{ Follicles } \\
\hline & F1 & F2 & F3 & F4 & F5 & F6 \\
\hline \multirow{7}{*}{ P0 } & 1.6 & 1.5 & 1.13 & 0.9 & & \\
\hline & 1.58 & 1.44 & 1.06 & 0.7 & & \\
\hline & 1.78 & 1.46 & 1.36 & 0.94 & 0.56 & 0.4 \\
\hline & 1.61 & 1.38 & 1.24 & 0.73 & 0.45 & \\
\hline & 1.73 & 1.5 & 0.9 & 0.5 & & \\
\hline & 1.9 & 1.7 & 1.54 & 0.88 & 0.57 & 0.38 \\
\hline & 2.2 & 1.84 & 1.22 & 0.82 & 0.48 & \\
\hline \multirow{7}{*}{ P1 } & 1.36 & 1.26 & 0.75 & 0.5 & 0.4 & \\
\hline & 1.8 & 1.47 & 0.65 & 0.5 & 0.4 & 0.2 \\
\hline & 1.66 & 1.28 & 0.65 & 0.36 & & \\
\hline & 1.57 & 1.21 & 0.5 & 0.2 & & \\
\hline & 1.7 & 1.00 & 0.46 & 0.44 & 0.39 & \\
\hline & 1.9 & 1.65 & 0.75 & 0.65 & 0.4 & 0.2 \\
\hline & 1.6 & 1.5 & 1.3 & 0.9 & 0.5 & \\
\hline \multirow{7}{*}{$\mathbf{P 2}$} & 1.1 & 0.8 & 0.5 & 0.3 & & \\
\hline & 1.93 & 1.68 & 1.2 & 0.9 & 0.51 & 0.3 \\
\hline & 1.67 & 1.54 & 1.35 & 1.19 & 0.74 & 0.5 \\
\hline & 1.58 & 1.35 & 0.88 & 0.54 & & \\
\hline & 1.84 & 1.46 & 0.93 & 0.68 & 0.38 & \\
\hline & 1.6 & 1.3 & 0.9 & 0.63 & 0.4 & 0.2 \\
\hline & 1.5 & 1.2 & 0.6 & 0.55 & & \\
\hline \multirow{7}{*}{ P3 } & 1.75 & 1.35 & 1.2 & 0.8 & 0.5 & 0.4 \\
\hline & 1.7 & 1.4 & 1.17 & 0.93 & 0.63 & 0.3 \\
\hline & 1.55 & 1.38 & 1.03 & 0.63 & & \\
\hline & 1.6 & 1.3 & 0.94 & 0.56 & & \\
\hline & 1.98 & 1.63 & 1.16 & 0.43 & 0.42 & \\
\hline & 1.78 & 1.56 & 1.1 & 0.76 & 0.46 & \\
\hline & 1.9 & 1.83 & 1.21 & 0.9 & 0.7 & 0.4 \\
\hline
\end{tabular}

P0: Control, P1: Vaccinated with hepatitis B vaccine, P2: Vaccinated with hepatitis B vaccine and given $12 \mathrm{mg} /$ quail/day of curcumin supplement, P3: Vaccinated with hepatitis B vaccine and given $108 \mathrm{mg} /$ quail/day of turmeric powder supplement. F1-F6: Follicle hierarchy from the largest (F1) to the smallest (F6) 


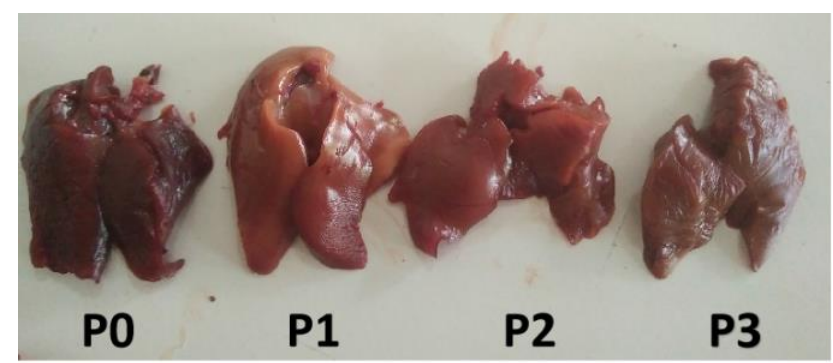

Figure 1. Livers of the quails in experimental groups at age of three months. P0: Control, P1: Vaccinated with hepatitis $\mathrm{B}$ vaccine, $\mathrm{P} 2$ : Vaccinated with hepatitis $\mathrm{B}$ vaccine and given 12 $\mathrm{mg} /$ quail/day of curcumin supplement, P3: Vaccinated with hepatitis B vaccine and given $108 \mathrm{mg} /$ quail/day of turmeric powder supplement

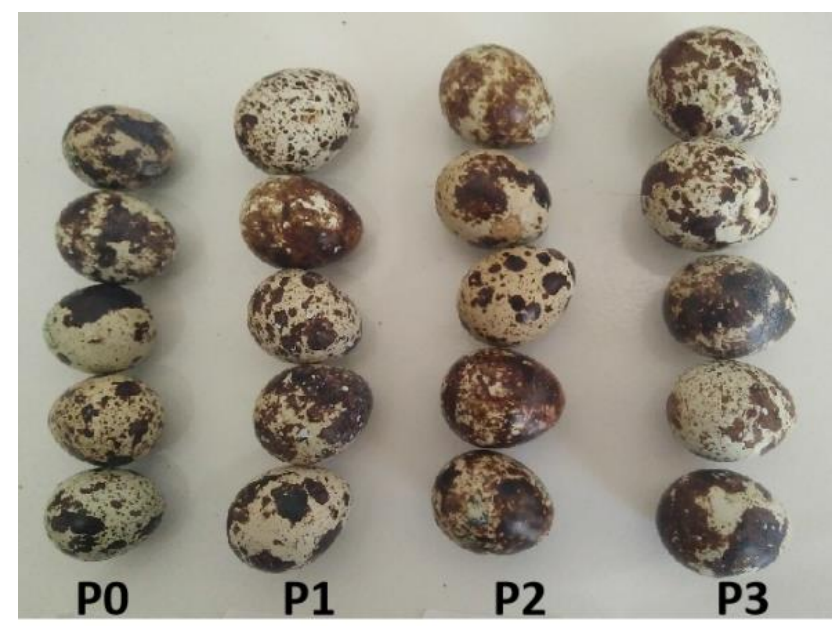

Figure 2. Eggs of the quails in experimental groups at age of three months. P0: Control, P1: Vaccinated with hepatitis B vaccine, P2: Vaccinated with hepatitis $\mathrm{B}$ vaccine and given 12 $\mathrm{mg} /$ quail/day of curcumin supplement, P3: Vaccinated with hepatitis B vaccine and given $108 \mathrm{mg} / q u a i l / d a y$ of turmeric powder supplement



Figure 3. Hierarchy of quails' ovarian follicles in every experimental groups at age of three months. P0: Control, P1: Vaccinated with hepatitis B vaccine, P2: Vaccinated with hepatitis B vaccine and given $12 \mathrm{mg} /$ quail/day of curcumin supplement, P3: Vaccinated with hepatitis B vaccine and given $108 \mathrm{mg} /$ quail/day of turmeric powder supplement

\section{DISCUSSION}

The observations revealed that there were no significant differences in the effects of hepatitis B vaccines, curcumin supplementation, and turmeric powder on liver weight. Similarly, the SGOT levels did not show notable different results, but there were significant differences in SGPT levels. There was a significant difference between the control group and the quails vaccinated with the hepatitis $\mathrm{B}$ vaccine (P1), quails vaccinated with hepatitis B then given a curcumin supplement (P2), and quails vaccinated with hepatitis $\mathrm{B}$ and then given turmeric powder supplement (P3). The SGPT levels decreased in P1. The average egg production increased $\mathrm{P} 1$.

Curcumin supplements and turmeric powder provision in the quails vaccinated with hepatitis B did not affect liver weight. This means that there was no damage to the liver, which was supported by normal-looking liver morphology presented in Figure 1.

Based on the liver morphology, it can be seen that the quails without any treatment (P0) had a brown-colored liver, whereas in treatment P1 and P2 the liver looked brighter. The showed color of the liver in treatment P1, P2, and P3 were more active in the process of vitellogenesis which resulted in partial vitellogenin stored in the liver. This phenomenon was similar to the results of a previous study by Saraswati and Tana (2016) indicating that the active liver producing vitellogenin looked bright brown. Some of the vitellogenin passes through the bloodstream to the ovaries for follicular development so that the weight of the liver does not differ significantly. The activity of liver function in producing vitellogenin was also indicated by the amount of egg produced by treated quails. Even though the activity increased, liver function remained normal which was indicated by SGPT and SGOT levels that were still in the normal range. In addition, there was even a decrease in SGPT levels in the quails vaccinated with hepatitis $\mathrm{B}$ meaning that the vaccination of hepatitis $B$ vaccine can improve liver function.

The given treatment, whether only Hepatitis B vaccination was received or the diet with the addition of turmeric powder and curcumin supplementation, could improve egg production. Furthermore, it could also improve the chemical and physical qualities of eggs, increase protein levels, and decrease levels of fat, carbohydrates, and cholesterol in eggs. The increase in protein levels was thought to be due to vaccination which would increase the production of immunoglobulin proteins 
and would be accumulated through the bloodstream, together with vitellogenin, going to the ovarian follicles.

The statistical analysis in the influence of hepatitis B vaccination and curcumin and turmeric powder supplementation showed significantly different results on the egg axis length, egg weight, egg yolk weight, egg white weight, high egg yolk, egg white height, eggshell thickness, yolk index, and Haugh Unit, but there was no difference in the width of the egg axis and the diameter of the egg yolk.

The physical quality of the eggs was also better as indicated by the increase in the size of the egg axis length, egg weight, egg yolk height, egg white height, egg yolk weight, egg white weight, yolk index, Haugh Unit, Eggshell Index. Those observations can be seen in Figure 2.

Another factor proving that the production and the quality of eggs produced by the quails vaccinated with hepatitis B vaccine and given supplements of curcumin and turmeric powder were higher can be observed from the hierarchy of ovarian follicles. An increase in the number and size of the hierarchy of ovarian follicles is shown in Figure 3 and Table 4.

\section{CONCLUSION}

Based on the results in the current research, the quails vaccinated with hepatitis $B$ vaccine and given supplements of curcumin and turmeric powder could produce eggs containing high protein with low fat and cholesterol levels, so that they can be used as an alternative in producing eggs as a supplement for hepatitis sufferers. Quail vaccinated with hepatitis $B$ vaccine 2 times at the age of 30 and 60 days and given a curcumin supplement $12 \mathrm{mg} /$ quail/day (P2) produced the highest egg productivity and the best egg quality in the form of the highest Yolk Index and more developed follicular hierarchy.

\section{DECLARATIONS}

\section{Author's contribution}

Tyas Rini Saraswati developed the concept, analyzed data, and wrote the manuscript. Silvana Tana assisted in data collection. All authors reviewed and confirmed the manuscript before submission.

\section{Acknowledgments}

This article was a part of the results of research funded by PNBP-RPP 2019-2020. Our gratitude goes to the Directorate General of Higher Education and LPPMUniversitas, Diponegoro, Indonesia.

\section{Competing interests}

The authors declare that they have no competing interests.

\section{Ethical consideration}

The author checked the manuscript to ensure that there are no ethical issues, including plagiarism, consent to publish, misconduct, data fabrication and/or falsification, double publication and/or submission, and redundancy.

\section{REFERENCES}

Chattopadhyay I, Biswa K, Bandyopadhyay U and Banerjeeil RK (2004). Turmeric and Curcumin: Biological action and medicinal applications. Review article. Current Science, 87: 44-53. Available at: http://repository.ias.ac.in/5196/1/306.pdf

Damme PV (2016). Long-term protection after Hepatitis B vaccine. The Journal of Infectious Diseases, 214: 1-3. DOI: https://www.doi.org/10.1093/infdis/jiv750

Gantait A, Barman T and Mukherjee PK (2011). Validated method for estimation of curcumin in turmeric powder. Indian Journal of Traditional Knowledge, 10: 247-250. Available at: http://nopr.niscair.res.in/bitstream/123456789/11499/1/IJTK \%2010\%282\%29\%20247-250.pdf

Jefferies M, Rauff B, Rashid H, Lam T, and Rafiq S (2018). Update on global epidemiology of viral hepatitis and preventive strategies.World Journal of Clinical Cases, 6: 589-599.

DOI: https://www.doi.org/10.12998/wjcc.v6.i13.589

Kohli K, Ali J, Antasari MJ, and Raheman Z (2005). A natural antiinflamatory agent. Education Forum, 37: 141-147. DOI: https://www.doi.org/10.4103/0253-7613.16209

Levi L, Pekarski I, Gutman E, Fortina P, Hyslop T, Biran J, Levavi B and Lubzens E (2009). Revealing genes associated with vitellogenesis in the liver of the zebrafish (Danio rerio) by transcriptome profiling. BMC Genomics, 10: 1-17. Available at: http://www.biomedcentral.com/1471$\underline{2164 / 10 / 141}$

Liang TJ (2009). Hepatitis B: The virus and disease. Hepatology, 49: 13-21. DOI: https://www.doi.org/10.1002/hep.22881

Mahaboob S, Reddy J, and Basha J (2013). A study on serum enzyme levels in various liver diseases. International Journal of Medical Research \& Health Sciences, 2: 395-398. DOI: https://www.doi.org/10.5958/j.2319-5886.2.3.069

Mattjik AA, and Sumertajaya IM (2006). Experimental design with SAS and Minitab application, IPB Press, Bogor. https://books.google.co.id/books?hl=en\&lr=\&id=wb38DwA AQBAJ\&oi=fnd\&pg=PP1\&dq=Sumertajaya. $+2006 .+$ Peran cangan+Percobaan:+dengan+aplikasi+SAS+dan+MINITAB + Book\&ots $=$ E5 UaXN-

nUM\&sig=tcmaOuoRtefR9EqUVrNyPt4AE1w\&redir_esc $=$ $\mathrm{y} \# \mathrm{v}=$ onepage $\& \mathrm{q} \& \mathrm{f}=$ false 
Munhoz LS, Vargas GD, Fischer G, Lima M, Esteves PA, and Hubner SO (2014). Avian IgY antibodies: Characteristics and applications in immunodiagnostic. Ciencia Rural, 44: 153-160. DOI: https://www.doi.org/10.1590/S0103$\underline{84782014000100025}$

Nagpal M, and Sood S (2013). Role of curcumin in systemic and oral health: An overview. Journal of Natural Science, Biology and Medicine, 4:3-7. DOI: https://www.doi.org/10.4103/0976-9668.107253

Nelson NP, Easterbrook PJ, and McMahon BJ (2016). Epidemiology of Hepatitis B virus infection and impact of vaccination on disease. Clinical Liver Disease, 20: 607-628. DOI: https://www.doi.org/10.1016/j.cld.2016.06.006

Ogunwole OA, Ojelade AYP, Oyewo MO, and Essien EA (2015). Proximate composition and physical characteristics of eggs from laying chickens fed different proprietary vitamin-mineral premixes under two rearing systems during storage. International Journal of Food Science and Nutrition Engineering, 5: 59-67. DOI: https://www.doi.org/10.5923/j.food.20150501.08

Ott JJ, Steven GA, Groeger J and Wiersa T (2012). Global epidemiology of Hepatitis B virus infection: New estimates of age-specificHBsAg seroprevalence and endemicity. Vaccine, 30: 2212-2219. DOI: https://www.doi.org/10.1016/j.vaccine.2011.12.116

Puwastien P, Siong TE, Kantasubrata J, Caven G, Felicionoand RR, and Judprasong K (2011). Asean Manual of food analysis. Regional centre of Asean network of food data system. Institute of Nutrition, Mahidol University Thailand, p. $196 . \quad$ Available at: https://inmu2.mahidol.ac.th/aseanfoods/doc/ASEAN\%20Ma nual $\% 20$ of $\% 20$ Food $\% 20$ Analysis.pdf

Ravindar PN, Babu KN, and Sivaraman K (2007). Turmeric the genus curcuma. CRC Press. London, New York. Available at: $\quad$ https://www.routledge.com/Turmeric-The-genusCurcuma/Ravindran-BabuSivaraman/p/book/9780849370342

Renantriandani KW, Maimunah U, Purwono PB, and Handajani $R$ (2020). The appearance of hbeag status in patients with chronic Hepatitis B virus. Indian Journal of Public Health Research and Development, 11: 1329-1335. DOI: https://www.doi.org/10.37506/ijphrd.v11i6.9988

Saraswati TR, Manalu W, Ekastuti DR, and Kusumorini N (2013a). Increased egg production of Japanese quail (Coturnix japonica) by improving liver funcion through turmeric powder supplementation. International journal of poultry Science, 12: 601-614. DOI: https://www.doi.org/10.3923/ijps.2013.601.614

Saraswati TR, Manalu W, Ekastuti DR and Kusumorini N (2014). Effect of turmeric powder to estriol and progesterone hormon profile of aying hens during one cycle of ovulation. International Journal of Poultry Science, 13: 504-509.

DOI: https://www.doi.org/10.3923/ijps.2014.504.509

Saraswati TR, Manalu W, Ekastuti DR and Kusumorini N (2013b). The role of turmeric powder in lipid metabolism and the effect on the quality of the first quail's egg. The Journal of The Indonesian tropical Animal Agriculture, 38: 123-130.

DOI: https://www.doi.org/10.14710/jitaa.38.2.123-130

Saraswati TR, and Tana S (2016). Effect of turmeric powder supplementation upon the age of sexual maturity, physical, and chemical quality of the first Japanese quail (Coturnix Japonica) egg. biosaintifika. Journal of Biology and Biology Education, $\quad 8: \quad 18-24$. DOI: https://www.doi.org/10.15294/biosaintifika.v8i1.4982

Shweta, and Prasad RR (2016). Liver function tests in acute hepatitis in children. International Journal of Research in Medical Sciences, 4: 3184-3187. DOI: http://www.dx.doi.org/10.18203/2320$\underline{6012 . i j r m s 20162160}$

Turker H, and Bozcaarmutlu A (2009). Effect of total isoflavones found in soybean on vitellogenin production in common carp. Research article. Kafkas Universitesi Veteriner Fakultesi Dergisi, 15: 561-568. Available at: https://agris.fao.org/agrissearch/search.do?recordID=TR2010001905 